\title{
Transformational Leadership and Organizational Culture at The Institute for Islam Studies Jember
}

\author{
Risqina \\ Institute for Islam Studies Jember \\ queenakun0511@gmail.com
}

Selfi Budi Helpiastuti

University of Jember

selfibudihelpiastuti@unej.ac.id

Sasongko

University of Jember

sasongko,fisip@unej.ac.id

\begin{abstract}
This study examines transformative leadership and organizational culture implemented in tertiary institutions. Transformational leaders have an impact on the effectiveness of organizational culture. This paper is based on the study of leadership theory, references about the culture of knowledge organizations, which integrate concepts and facts in the field. Of course the transformation process has an impact on organizational culture including students. Not only does it change the work rhythm that is demanded to be bigger, but more students being taken care of are also more complicated. This reality ultimately also has an impact on habits including good employee performance due to the reduced number of present workforce recruited. The purpose of this study is to examine and discuss the characteristics of transformational leadership and organizational culture at Islamic Institute of Religion Jember. This type of research is field research. The research method used is a qualitative research method. While the data collection methods used are interviews, observation and documentation. The validity test of the data used is triangulation, confirmation of reliability, transferability and dependability. While the analysis of the data used is an interactive analysis of Miles Huberman. The results of the conclusions in this study indicate that Transformational Leadership is built by three factors, namely Inspirational in shaping vision and ideas, visionary in articulating vision \& mission and intellectual support to achieve targets and goals. Transformational leadership provides a change in work support and team performance. Strong leadership in providing work motivation, stimulating concepts or ideas to group or individual employees can produce harmony in achieving a shared vision, team commitment, work culture and minimal conflict. Transformative leadership needs to improve communication in building a positive organizational culture because communication of leadership and work increases the culture of teamwork, cohesion and conflict.
\end{abstract}

Keywords: Transformational Leaders, Organizational Culture, Employee Performance

\section{INTRODUCTION}

Transformational leadership is one of the many models of leadership, according to Tracey and Hinkin (1998) as a process of increasing mutual leadership and followers to a higher level of morality and motivation. Transformational leaders are leaders who inspire their followers to put aside their personal interests for the good of the organization and they are able to have an extraordinary influence on their followers. They pay attention to the self-development needs of their followers, change followers' 
awareness of existing issues by helping others see old problems in new ways, and are able to please and inspire followers to work hard to achieve common goals (Robbins and Judge, 2008: 90).

The capacity of each employee differs from one another, and that potential can be developed and directed. The amount of capacity is usually greater than the apparent ability (achievement) that is seen. In this case it is the duty of the leadership of the agency to explore, channel and develop the capacity of its employees in order to improve performance. In addition to leadership, organizational culture is one important factor that helps employee performance. Organizational culture is able to create a level of motivation for employees to provide the best ability to take advantage of the opportunities provided by the organization. A culture that grows to be strong is able to drive the organization to a better direction (Robbins, 2006). Organizational culture (corporate culture) is often interpreted as symbol values that are understood and adhered to together, owned by an organization so that members of the organization feel one family and create a condition that members of the organization feel different from other organizations (Waridin and Masrurukhin, 2006).

Support and participation of all members of the organization involved is needed to realize the right organizational culture. The shared culture is expected to make employees feel comfortable working, have loyalty and give satisfaction to the work of employees so that they will always show their best performance. Job satisfaction is a positive feeling about one's work that is the result of an evaluation of its characteristics (Robbins and Judge, 2008: 107). According to Luthans (2006: 243), there are five dimensions of job satisfaction, namely: payment, work itself, promotion opportunities, supervisors, and coworkers.

Hughes et al. (2012: 337) states that job satisfaction is related to one's attitude about work, and there are several reasons that make job satisfaction an important concept for leaders. Research shows satisfied workers are more likely to stay working for the organization. Satisfied workers also tend to engage in organizational behavior that goes beyond their job descriptions and roles, and helps reduce the workload and stress levels of other members in the organization. Dissatisfied workers tend to be resistant in relation to leadership and engage in counter-productive behaviors. Dissatisfaction is also the main reason someone leaves the organization. This study aims to examine the characteristics of transformational leadership on organizational culture and on employee performance.

Whether transformational leadership is enhanced will increase employee performance. Because, leadership and organizational culture are both positive and significant influence on performance through job satisfaction. This indicates that leadership supported by a strong organizational culture will result in high job satisfaction which in turn has an effect on improving employee performance.

\section{RESEARCH METHODE}

The type of research used in this study is Field research. The research method used is to use a qualitative approach that emphasizes understanding patterns, relationships that 
are built through facts, concepts and theories using narration. While the data collection methods used are interviews both through structured interviews using interview guides and in-depth interviews by asking directly to informants or participants regarding the questions asked. The second data collection technique uses guided observation with more observation guides on the emphasis of events, phenomena and realities that occur in the field and the third is the method of documentation that emphasizes documents, archives, images, artifacts and other securities that help complement research data. The validity test of the data used is triangulation both techniques and triangulation of sources with the validity test that is confirmability, tranferability and dependability. While the analysis of the data used is an interactive analysis of Miles Huberman who uses certain taxonomies to be analyzed, Data findings and research discussion.

\section{DATA FINDINGS AND RESEARCH DISCUSSION}

\section{A. Transformational leadership}

\section{Transformational leadership in initiating ideas}

Transformational leadership Based on research, at the Religient Institute Of Java Jember the most prominent indicator of the leadership variable at the institution is Transformational Leadership which emphasizes idealized influence (ideal influence). This ideal influence has been demonstrated by the leader in this case the chancellor in the form of the emergence of subordinates' trust in the chancellor. The ideal influence of a chancellor is clearly not without proof, the pride and trust of employees arises because what is being targeted can be achieved, one of which is changing the status of the Religient Institute Of Java Jember to the Religient Institute Of Java Jember. The struggle requires many instruments that must be prepared both in terms of facilities and infrastructure, the number of teaching staff and the number of students. Besides that, it is to equalize the perceptions of various campus stakeholders to jointly strengthen the steps towards changing status. In addition, the chancellor's ability to convince the Ministry of Religion to be categorized as suitable for status transfer. This ability is not shared by everyone. The ability to provide the ideal influence of this leader will still be used for the next status change effort towards State Islamic University Jember. Proven support of all parties both lecturers, students and employees support the change of status change. This support is a form of employee pride for their leader who has clearly demonstrated that he is the ideal leader for employees.

\section{Transformasinal leadership in providing stimulus}

The second indicator that is generally perceived well by employees at Institute Religion Of Java Jember is intellectual stimulation. The form of intellectual stimulation is the behavior of leaders who are able to direct subordinates to problem solving carefully. The Chancellor in every event always urges employees to use their creativity in solving work problems so that they are meticulously addressed. Not all things / problems have to be the chancellor who is coping. Gradually the problem must be able to be overcome 
at the unit level. This subordinate creativity must be consulted first with his direct supervisor as the person in charge of the work of his subordinates. Of course the space given for creativity is given as long as it does not violate existing laws and regulations. Thus the employee feels happy because he feels at least he has a contribution to overcome problems in the scope of his work.

Employee performance in implementation can be influenced by several factors. According to Wirawan (2009: 6) these factors are organizational internal environmental factors, external environmental factors and internal employee factors. Things that come into the organization's internal environmental factors include support from the workplace of employees in carrying out their duties which will later affect the resulting performance for example, organizational culture, leadership, compensation systems, work climate, and management systems. The factors that will be used in this study are organizational culture and leadership factors.

In The Context Of Transferring Status To State Islamic University, the leadership at Institute Religien Of Java Jember implemented a strategy in producing various excellent programs. Speech from the Vice Chancellor for Academic Affairs, on 11 November 2019 about the strategy taken by the leadership in the framework of the transformation process of Institute for Islam Studies Jember.

According to Vice Chancellor I, the strategy that brought Institute for Islam Studies is growing even as a foundation to accelerate the transfer of status from Institute for Islam Studies Jember to State Islamic University Jember, the implementation is: encouraging as much scientific publications, acceptance programs for permanent government employees Lecturers, acceptance of Non government employees permanent Lecturers, recruitment of employees or Mutation Lecturers, provide funding and support for lecturers who take the Doctoral program (S3), provide support and licensing to lecturers and staff to continue their studies to a higher level, give additional tasks to lecturers who have completed doctoral studies, provide motivation to lecturers- lecturers to immediately get promoted by taking part in the Post Doctoral Program for all Lecturers who are already Doctors and giving motivation and full support to lecturers who have doctorates to immediately move up to become professors. Most of the emphasis is on improving the quality of Human Resources because Institute for Islam Studies Jember has the task of printing Human Resources as the next generation of religious, intelligent and independent nation. Based on observations from the Vice Chancellor I speech above, leadership at the state Islamic religion institute Jember is transformational leadership that is very compatible with the process of organizational transformation that is being carried out, namely the effort to change status to State Islamic University Jember.

\section{Transformational leadership in building vision and mission}

Inspirational Motivation is given by the rector of state Islamic religion institute Jember on almost every occasion of a meeting or activity. The Chancellor always strives to improve the morale of employees of both Civil Servants and vice versa by granting 
study permits to a higher level of education, encouraging as much scientific publicity as possible, providing assistance for writing international journals, assistance for completing Doctoral degrees for educators and education staff Civil servants and nongovernment employees, assistance to complete S-2 for civil servants and nongovernment employeeseducation staff, assistance of completion of bachelor degree for non-civil servant education staff, organizes post doctoral programs for lecturers who have completed S-3 in order to immediately obtain a professor degree. The lecturers became eager to complete their education and were also eager to win a professorship because of this motivation. The reality is that at the end of 2016, a lecturer was nearing retirement in early 2017, because of the encouragement and motivation from the chancellor the lecturer was finally able to complete the requirements to achieve a professor degree a month before he retired. The addition of professors is one of the strong motivations for the role of transformational leadership. So what was given by the chancellor as a leader at state Islamic religion institute Jember was not just motivation in the form of words but a tangible form that truly gave enthusiasm to the employees.

Individualized Consideration is the behavior of leaders who pay attention to the work needs of subordinates, respect individual differences and give direction to subordinates. The Chancellor as the highest leader In Institute Religien Of Java Jember respects individual differences by always treating each subordinate as an individual with different needs and abilities. For example, in terms of clothing in the office it is not specified that certain models should only be Monday and Tuesday must wear white tops and dark subordinates. In addition to that day, it is not specified that you have to wear certain uniforms, only Muslim clothing that covers the nakedness. However, in some faculties there are rules that apply, for example, female lecturers are required to wear subordinate skirts when teaching and tops below the knee. Employees who wear the veil are not permitted to use during working hours. So for the clothes to the office does not determine the problem of color and model of clothes, tailored to the tastes of each employee, as long as Muslim clothes cover the genitals.

The Needs Of Institute of Islamic Religion Jember employees vary, in this case what is discussed is the employee's personal development needs regarding his needs in terms of training, seminars, workshops and other things that can support the implementation of employee work. Of Institute of Islamic Religion Jember Jember leaders always budget funds for employee capacity building events both at Of Institute of Islamic Religion Jember Jember and events organized by outside agencies such as other universities or training centers. This does not only apply to certain structural officials and functional employees but also to general functional employees, SPDs are provided to attend employee self-development events if carried out by outside agencies. This is necessary for employees because it will be related to professionalism.

Another form of individual consideration carried out by the chancellor is to often give direction to employees both in formal events such as meetings and ceremonies on the 17th of each month, as well as in informal events such as every meeting when passing by. give briefings and advice to the employee. 
The findings of this study support Amil's (2008) study which states that there is a positive and significant influence between Leadership on Job Satisfaction of NonEducative Employees at Muhammadiyah University, Mataram, West Nusa Tenggara. This finding also supports research conducted by Yang, Mu-Li (2012), finding that the transformational leadership dimension has a significant influence on job satisfaction and organizational commitment.

\section{B. Characteristics of Organizational Culture}

The next factor is the organizational culture at Institute of Islamic Religion Jember which has been instilled since the establishment of Institute of Islamic ReligionJember Jember. The culture is related to Islamic culture, academic culture and local culture. The culture of this organization is to differentiate it from other tertiary institutions by presenting routines and rhythms such as: as a college committed to the Islamic archipelago, the competitiveness strategy appears in the Santri Day celebrations, recitation of the Prophet's blessings sung by the Of Institute of Islamic Religion Jember Jember Student Choir in each event, traditional religious dances in every event, national anthem and Santri songs in every event.

According to Martoyo, Deputy Dean III of the Sharia Faculty, the academic culture at Institute of Islamic Religion Jember is in the form of organic intellectuals, intellectuals who have autonomy, are independent and cannot be swayed. So academics must be the engine of change. The driving force of enlightenment, the motor of marginalization of the community, so that achievements are highlighted. So here, Institute of Islamic Religion Jember prioritizes the quality of competition culture, healthy competence and prioritizes unity. Can compete but must be polite and dignified. Besides that the academic culture that is already familiar among students is the culture of academics which consists of indicators: like reading, like discussion, like writing, and like research. Can be seen in daily activities, for example holding seminars by student activity unit, music development culture, self-defense in student activity unit. (interview on November 8, 2019)

Other innovations on the internalization of the nationalism-based Islamic values of Nusantara as Jain's Of Institute of Islamic ReligionJember Into Various Activities. Institute of Islamic Religion Jember Into Various Activities vision is to become a Center for the Study and Development of Nusantara Islamic International. In order to achieve these big goals, Institute of Islamic Religion Jember Into Various Activities Jember requires and instructs the entire academic community of Institute of Islamic Religion Jember Into Various Activities Jember to carry out various activities in the nuances of the Archipelago Islam. There are several things done by Institute of Islamic Religion Jember Into Various Activities in internalizing Islamic Nusantara values into various Institute of Islamic Religion Jember Into Various Activities Of Java Jember activities, namely: Nusantara Islam became a compulsory subject that must be taken by all Institute of Islamic Religion Jember Into Various Activities Jember students, the 
seminars held were inseparable with the theme of Islamic Nusantara and national seminars, National Santri Day activities as a moment of strengthening the values of the Archipelago Islam and each faculty and units carry out activities in the process of internalizing the values of the Archipelago Islam.

In order to build solidity based on enlivening the culture of local wisdom, a program laden with respect for local culture and customs, and as a form of implementation in building a conducive campus environment between leaders, lecturers, employees and students is a routine activity organized by In Institute of Islamic Religion Jember Into Various Activities Jember, namely: carry out physical health programs every Friday, silaturrahim held by each faculty every month of Ramadan Institute of Islamic Religion Jember Into Various Activities Jember birthday celebrations, joint opening program held every month of Ramadan, halal bihalal which is held every post Idulul Fitri Eid holidays, ceremonies every 17th of each month, cultural tasyakuran, a culture of shaking hands by shaking hands and smiling when meeting both leaders, lecturers, employees, employees and students.

In addition, the Chancellor recently instructed all employees, lecturers and students to start loving the environment in the form of always carrying their own drinking water bottles and the campus providing water, to minimize plastic waste and funds for drinking. Began to instill a culture of loving the environment.

Thus based on the description above it can be conveyed interesting things according to the author about Institute of Islamic Religion Jember Into Various Activities Jember so that it is used as a place for research, including the process of organizational change / transformation that is being fought very quickly, because recently in 2015 the status changed from Islamic Higher School to Institute of Islamic Religion Jember Into Various Activities Jember, When This Is In The Process Of Submitting A Status Transfer To State Islamic University. In line with the characteristics of the leaders in Institute of Islamic Religion Jember Into Various Activities Jember who are transformed to want changes to be made in a fast time, do not hesitate to go straight down, and also the Islamic culture that is applied in everyday relationships. These things are interesting to study because of the complexity of the variables that are the cause, which is not always a problem, there may be other problems that may have a greater effect. These issues are examined in relation to transformational leadership, organizational culture, job satisfaction and performance. This study examines and analyzes the direct effect of transformational leadership on job satisfaction, the direct influence of organizational culture on job satisfaction, and the direct effect of transformational leadership on performance, the influence of organizational culture on performance and the effect of job satisfaction on employee performance at Institute of Islamic Religion Jember Into Various Activities Jember

Institute of Islamic Religion Jember Into Various Activities Jember as one of the religious universities in Jember, is an educational institution consisting of members of the organization, namely the Chancellor, structural officials, teaching staff, and education staff as well as students. The components of the organization are interrelated and support each other in carrying out educational activities in order to provide the 
best service for the community. If all components of the organization can be united, it is expected that the output produced will have high competitiveness.

Educators and educational staff are expected to be able to complete and carry out their respective duties in order to provide the best service to the academic community. The existence of educational staff regardless of position and status needs to be a concern of the leadership of the institution, given the importance of the task of educational staff in maintaining the sustainability of the organization, it is hoped that they can also be a driving force to carry out their duties properly. The point is that they should be able to respond quickly to the situation around them, act without waiting for orders, and not calculate their duties.

Based on research at Institute of Islamic Religion Jember Into Various Activities Jember, it turns out that indicators for Organizational Culture are organizational culture as a differentiator, namely Institute of Islamic ReligionJember Into Various Activities Jember, a university that implements and upholds Islamic valuesin the campus environment so that it is different from other organizations. Basically, the culture in every college may be the same, namely the existence of an academic culture, but what makes the difference is the Islamic valuesthat are applied in daily life on campus. The easiest to find is on the Jain Institute Religien campus, all women wearing hijab, both employees and students. Then in terms of social relations are also based on Islamic law. As a tertiary institution committed to the Islamic archipelago, the competitiveness strategy to present organizational culture as a differentiator appears in the Santri Day Celebration, Recitation Of The Prophet's Blessings Sung By The Institute of Islamic Religion Jember Student Choir in each event, traditional religious dances in each event, song singing the nationality and Santri songs in each event.

The next indicator is organizational culture carries a sense of organizational identity. Institute of Islamic Religion Jember is an organization that has cultural values that are characteristic / identity for its members. The developing culture aims to strengthen the existing identity, for example the opening of Ma'had Al-Jami'ah, son and daughter and mosque with the archipelago architecture, even his name was also taken from one of the guardians of Islamic propagators in the archipelago, especially in Java, namely the "sunan ampel" mosque and "Sunan Kalijogo" mosque. The commitment of the Islamic Archipelago as a reference in designing the culture of Islamic higher education is based on the wisdom of the archipelago's Islam by not only focusing on modernity or science and technology. With the stipulation of Santri Day as National Day by the government, the culture that is celebrated is increasing, namely the celebration of Santri Day every October 22. The event involved all employees and students of Institute Religien Of Java Jember. The event consisted of 1) Archipelago Islamic Insights Seminar attended by all Jember institute religien of javAacademic community and invited the heads and staff of the Jember Regency Ministry of Religion office, 2) carnival around the campus followed by all Jember Institute Religien academic community wearing Santri-style clothes, male wearing koko and gloved clothes, while women wearing Muslim clothes and for an interesting Event the event 
ends with a coupon and door prize with prizes. It was at this time that fostered brotherhood and understanding of the importance of religious culture wrapped in togetherness.

The third indicator, Organizational Culture facilitates the emergence of commitment, meaning that cultural values in Institute Religien Of Java Jember are able to raise awareness for its members to commit to the interests of the organization rather than individual interests. Continuous communication from the Chairperson of Institute Religien Of Java Jember regarding the values That Must Become Culture. The Superior Culture Built At Institute Religien Of Java Jember is Academic Ethics, which are discipline, communication ethics and national ethics which are always echoed by the rector and his representatives both in the form of delivery when ceremonial events and in the form of routine programs.

Furthermore Organizational Culture is a social glue, meaning that cultural values that exist Institute for Islam Studies Jember are able to strengthen good relations between elements of leadership, lecturers, employees and students. One form of efforts in building a conducive campus environment between leaders, lecturers, employees and students is the existence of routine activities organized by Institute for Islam Studies Jember, namely: carrying out physical health programs every Friday, silaturrahim held by each faculty every month of Ramadan, Institute for Islam Studies birthday celebration, open program together which is held every month of Ramadhan, halal bihalal which is held every post Idul Fitri Eid holiday, ceremonies every 17th of every month, culture of thanksgiving, culture of shaking hands and smiling when meeting both leaders, employees, and students. A good atmosphere in the campus environment will help employees easily get job satisfaction.

The most prominent indicator of the variable Organizational Culture is organizational culture forming attitudes meaning that the cultural values that exist in Institute of Islamic Religion Jember are able to shape and control the attitudes and behaviors of employees to remain in accordance with Islamic values. Islamic values become a barrier for everyone to behave and behave in Institute Religien Of Java Jember. This concerns what is and is not allowed to be done, what is appropriate and inappropriate, what is good and not good to do is all regulated according to Islamic teachings that originate from the Qur'an and Hadith. The relationship between lecturers and students in lectures, relations between employees in work, and student relations with fellow students must follow the rules of Islam, because Institute Religien Of JavaJember applies Islamic teachings as a guide. In addition to Islamic cultural values, local cultural values also form the elements of the attitude of the employees and students of Institute Religient Of Java Jember. Mixed cultural values between Madurese and Javanese people known as pandhalungan, for example hospitality, courtesy, honesty, friendly attitude, consider brothers and sisters who are one area even though not known before, like to help and so on. The culture also influenced the formation and control of the attitude of the employees and students of Institute of Islamic Religion Jember. 
Thus at Institute of Islamic Religion Jember Organizational Culture creates a clear distinction between one organization and another, Culture carries a sense of identity for members of the organization, Culture makes it easier for commitment to something broader than one's individual self-interest, Culture is a social glue that helps uniting the organization by providing appropriate standards for employees, Culture as a mechanism for making meaning and control that guides and shapes employee attitudes and behavior. These things have led to the creation of job satisfaction for employees. In this case as an effort to increase employee Job Satisfaction, all organizational components in Institute of Islamic Religion Jember always strive to maintain and enhance a better Organizational Culture.

The findings of this study support research conducted by Julianto Romi Haryo and Susi Hendriani, (2014) on the Influence of Organizational Culture and Work Motivation on Job Satisfaction and Employee Performance in the Regional Office of the Directorate General of Customs and Excise (DJBC) Riau and West Sumatra. The results showed that organizational culture had a positive and significant effect on job satisfaction.

\section{CONCLUTION}

The foundation of transformational leadership is very dependent on three factors: the inspirational leader in formulating ideas and communicating to employees through communication in the work environment. Second, leadership can motivate themselves and skills to motivate others to improve their performance. The third leadership is able to communicate and articulate a vision and mission in achieving challenging goals. Transformative leadership is demanded to be able to exert influence and instill pride in subordinates so that organizational culture arises which encourages high work motivation for employees who face new organizational rhythms and new employees who are not yet accustomed to the work culture of organizations that have high adaptation demands. Transformational leadership must be able to provide peace of mind to subordinates who have high work pressure and are still new. Leaders must be able to convince subordinates that obstacles will be overcome, increased confidence in the achievement and implementation of goals and tasks, leaders are required to speak optimistically about the future, articulate an interesting vision for the future and provide an interesting picture of organizational culture change.

\section{REFERENCES}

Agung Kurniawan. 2006. Transformasi Pelayanan Publik. Yogyakarta.

Amil. 2008. Analisis Pengaruh Kepemimpinan dan Budaya Organisasi terhadap Kepuasan Kerja dan Kinerja Karyawan non Edukatif di Universitas Muhammadiyah Mataram Nusa Tenggara Barat. Universitas Jember. Program Magister Pascasarjana 
Al-Swidi, A.K. dan Mahmood, R. 2012. Total Quality Management, Entreprenurial Orientation and Organizational Performance: The Role of Organizational Culture. African Journal of Business Management. 6. 4717-4727.

Allen,N.J. dan Meyer,J.P. 1991. A Three-Component Conceptualization of Organizational Commitment, Human Resource Management Review, Vol 1, No 1, pp. 61-89.

Castillo, J.X., dan Cano, J. 2004. Factors Explaining Job Satisfaction Among Faculty,Journal of Agricultural Education, Vol 45, No 3, pp. 65-74.

Cavazotte,F.,Moreno,V., Hickmann, M. 2012. Effects of leader intelligence, personality and emotional intelligence on transformational leadership and managerial performance, The Leadership Quarterly,Vol 23, pp. 443 -455.

Dadang. 2012. Budaya Kerja Organisasi Pemerintah. Jakarta: Buku Seru.

Didit Dermawan. 2013. Prinsip - Prinsip Perilaku Organisasi. Surabaya: Pena

Eugene Mckenna dan Nic Beech. 2000. Manajemen Sumber Daya Manusia, Yogyakarta: Andi

Dimyati dan Mudjiono. 2009. Belajar dan Pembelajaran. Jakarta: PT. Rineka Cipta

Fauza, Desy Herma dan Yohan Wismantoro. 2014. Analisis Faktor-faktor yang Mempengaruhi Kinerja Pegawai Negeri Sipil pada Badan Pertanahan Nasional Kabupaten Boyolali. Media Ekonomi dan Teknologi Infomasi. 22(1). 71-89.

Garboua,L.L.,dan Montmarquette,C.2004. Reported Job Satisfaction: What does it mean?, Journal of Socio-Economics, Vol 33, No 2, pp. 135-151.

Gibson,J.L.,Ivancevich,J.M.,Donnelly Jr.2009.Organisasi: Perilaku, Struktur, Proses, Edisi Bahasa Indonesia, Tangerang: BinarupaAksara.

Goodwin,V.L., Wofford,J.C.,dan Whittington,J.L.2001. A Theoretical and Empirical Extension to the Transformational Leadership Construct, Journal of Organizational Behavior, Vol 22, No 7, pp.759-774.

Griffith,J. 2004. Relation of principal transformational leadership to school staff job satisfaction, staff turn over, and school performance, Journal of Educational Administration,Vol 42,No 3, pp. 333-356.

Hadi, Sutrisno dan Mujiasih, Endah, 2003. Pengaruh Gaya Kepemimpinan Transformasional dan Gaya Kepemimpinan Transaksional dan Pengaruhnya Terhadap Upaya Extra (extra effort) Pegawai Dinas Kesehatan Kota (DKK) Semarang, Salatiga, dan Kabupaten Semarang di Ungaran. Jurnal Bisnis dan Ekonomi, 10, 2, 198-208.

Hasibuan, Malayu. 2000. Manajemen Sumber Daya Manusia. Edisi Revisi.Jakarta: PT Bumi Aksara

Hughes, R.L., Ginnett, R.C., dan Curphy, G.J. 2012. Leadership: Memperkaya Pelajaran dari Pengalaman, Edisi Ketujuh. Jakarta: Salemba Humanika.

Husaini,U. 2008. Metode Penelitian untuk Skripsi dan Tesis Bisnis. Jakarta: PT Raja Grafindo Persada. 
Husein, Adi Kusnadar Zulkifli Ahmad. 2015. Pengaruh Tingkat Kecerdasan Emosional dan Karakteristik Individu Terhadap Kinerja Melalui Kepuasan Kerja Pegawai Lingkungan Sekretariat Pemerintah Daerah Kabupaten Jember. Tesis. Jember: Program Studi Manajemen, Universitas Jember.

Iqbal Nazili, 2012. Pengaruh Gaya Kepemimpinan Dan Iklim Organisasi Terhadap Kinerja Karyawan: Motivasi Kerja Sebagai Variabel Intervening, Skripsi Dipublikasikan.

Iksan, Anwar. 2016. Analisis Pengaruh Budaya Organisasi dan Kepuasan Kerja terhadap Kinerja Karyawan Non Dosen Pada Universitas Mercu Buana Jakarta. Jurnal Ilmiah Manajemen dan Bisnis, 2, 1, 17-35.

Jamaluddin. Rudi Salam, Harisman Yunus dan Haedar Akib. 2017. Pengaruh Budaya Organisasi terhadap Kinerja Pegawai pada Dinas Pendidikan Provinsi Sulawesi Selatan. Jurnal Pemikiran Ilmiah dan Pendidikan Administrasi Perkantoran,. 4, 1, 25-34

Julianto Romi Haryo dan Susi Hendriani. 2014. Pengaruh Budaya Organisasi dan Motivasi Kerja Terhadap Kepuasan Kerja dan Kinerja Pegawai Pada Kantor Wilayah Direktorat Jenderal Bea dan Cukai (DJBC) Riau dan Sumtera Barat. Jurnal Ekonomi. 22(2). 13-26

Kerlinger, Fred N., 1993, Asas-Asas Penelitian Behavioral, Edisi Indonesia, Yogyakarta: Gajah Mada University Press.

Krishnan,V.R. 2005. Leader-Member Exchange,Transformational Leadership, and Value System, Electronic Journal of Business Ethics and Organization Studies, Vol 10, No 1, pp. 14-21.

Mangkunegara. A., .2010. Manajemen Sumber Daya Manusia. Jakarta: Gramedia Widisarana Indonesia.

Mardiana, Tri. 2003. Studi Empiris Pengaruh Efektivitas Kepemimpinan terhadap Kinerja. Kompak, Jurnal UNY. Vol. 8 Mei-Agustus: 276-297

Muhdianto. 2006. Pengaruh Kepemimpinan Transformasional terhadap Kinerja yang Dimoderasi Kecerdasan Emosional (Studi Empiris di Kantor DPRD Kota dan Kabupaten Magelang).

Nguni, S.C., 2005. A Study of the Effects of Transformational Leadership on Teachers' JobSatisfaction, Organizational Commitmen tand Organizational Citizenship Behaviour in Tanzanian Primary and Secondary Schools, Doctoralthesis, Universiteit Nijmegen.

Peraturan Pemerintah Republik Indonesia Nomor 11 Tahun 2017. Manajemen Pegawai Negeri Sipil. 7 April 2017. Lembaran Negara Republik Indonesia Tahun 2017 Nomor 63. Jakarta.

Podungge, Abdul Wahab. 2018. Pengaruh Kepemimpinan Transformasional terhadap Peningkatan Kualitas Kinerja Pegawai di Dinas Pendidikan Kabupaten Bone Bolango. Gorontalo Journal of Public Administration Studies. 1(1): 56-68.

Prasetyo,B., dan Jannah,L.M. 2010. Metodologi Penelitian Kuantitatif: Teori dan Aplikasi, Jakarta: Rajawali Pers.

Rivai,V., dan Mulyadi,D. 2012.Kepemimpinan dan Perilaku Organisasi, Jakarta: Rajawali Pers. 
Robbins, S.P. 2000. Human Resources Development Concept and Practices, Jakarta: PT. Preenhalindo.

Robbins, S.P. 2002. Prinsip-prinsip Perilaku Organisasi, Edisi Kelima, Jakarta: Penerbit Erlangga.

Robbins, S.P. 2003. Perilaku Organisasi, Jilid I, alih bahasa Jakarta: PT Indeks Kelompok Gramedia.

Robbins, S.P. 2006. Perilaku Organisasi, Edisi Kesepuluh, alih bahasa Jakarta: PT Indeks Kelompok Gramedia.

Robbins, S.P., dan Judge, T.A. 2008. Perilaku Organisasi, Edisi Kedua belas, Jakarta: Salemba Empat.

Santoso, Djoko dan Ferdiyono, J. Reza. 2018. Pengaruh Remunerasi, Kepuasan Kerja Dan Kepemimpinan Transformasional Terhadap Kinerja Pegawai Dengan Organizational Citizen Behavior Sebagai Variabel Intervening Pada Seksi Bpkb Ditlantas Polda Jateng. Jurnal Riset Ekonomi dan Bisnis. 11, 3, 240-260.

Schleicher, J.D.,Watt, J.D., dan Greguras, G.J. 2004. Reexamining The Job SatisfactionPerformance Relationship: The Complexity of Attitudes, Journal of Applied Psychology, Vol 89, No 1, pp. 165-177.

Sedarmayanti. 2010. Manajemen Sumber Daya Manusia Reformasi Birokrasi dan Manajemen Pegawai Negeri Sipil. Bandung: PT. Refka Aditama.

Siagian, Sondang P. 2009. Manajemen Sumber Daya Manusia. Jakarta: Bumi Aksara. Edisi.l, Cetakan.17

Sinambela, Lijan Poltak. 2012. Kinerja Pegawai. Graha Ilmu: Yogyakarta.

Siregar, Syofian. 2013. Metode Penelitian Kuantitatif: dilengkapi perbandingan perhitungan manual dan SPSS Edisi Pertama. Jakarta: Kencana Prenada media Group.

Sopiah. 2008. Perilaku Organisasional, Yogyakarta: Penerbit Andi.

Sugiyono.2011. Metode Penelitian Kuantitatif, Kualitatifdan Re D.Bandung: Alfabeta.

Sunyoto, Danang., 2012, Manajemen Sumber Daya Manusia, Yogyakarta: CAPS (Center for Academic Publishing Service).

Tika, M.Pabundu. 2006. Budaya Organisasi dan Peningkatan Kinerja Perusahaan. Jakarta : PT. Bumi Aksara.

Tondok, M.S., dan Andarika, R. 2004. Hubungan Antara Persepsi Gaya Kepemimpinan Transformasional dan Transaksional dengan Kepuasan Kerja Karyawan. Jurnal PSYCHE. Vol 1, No 1, pp. 35-49.

Tracey, J. B., \& Hinkin, T. R. (1998). Transformational leadership or effective managerial practices?. Group \& Organization Management, 23(3), 220-236.

Tracey, J.B., dan Hinkin,T.R. 1998. Transformational leadership or effective managerial practices?,Group \& Organization Management. Vol 23,No 3,pp 220-236.

Umam, Khaerul. 2010. Perilaku Organisasi, Bandung: CV. Pustaka Setia.

Wright, J.D.,dan Hamilton,R.F.1978.Work Satisfaction and Age;Some Evidence forThe Job Change, Hypothesis,Social Force, Vol 56,pp. 1140-1158. 
Yang, Mu-Li. 2012. Transformational Leadership and Taiwanese Public Relations Practitioner" Job Satisfaction and Organizational Commitment,Social Behavior and Personality,Vol 40, No 1, pp.31-46.

Yang,Yi-Feng, dan Islam,M.2012.The Influence of Irans formational Leadership on Job Satisfaction:The Balanced Score card Perspective, Journal of Accounting \& Organizational Change,Vol 8, No 3, pp. 386-402.

Yukl, G. 2010. Kepemimpinan Dalam Organisasi. Edisi Indonesia. Jakarta: Penerbit PT Indeks.

Zahari,I., dan Shurbagi,A. 2012. The Effect of Organizational Culture and the Relationship between Transformational Leadership and Job Satisfaction in Petroleum Sector of Libya,International Business Research,Vol5,No9,pp.89-97. 